\title{
OPTIMIZATION OF PHYSICAL PARAMETERS OF A-AMYLASE PRODUCING BREVIBACILLUS BOROSTELENSIS R1 IN SUBMERGED FERMENTATION
}

\author{
K.Suribabu ${ }^{1}$, T. Lalitha Govardhan ${ }^{2}$, K.P.J Hemalatha ${ }^{3}$ \\ ${ }^{1,2}$ Assistant Professor, PG Department of Microbiology and Research Centre, Dr. Lankapalli Bullayya Post-graduate \\ College, Andhra Pradesh, India, Visakhapatnam-530 013 \\ ${ }^{3}$ Professor, Department Microbiology, Andhra University, Andhra Pradesh, India
}

\begin{abstract}
Bacteria have been regarded as treasure of many useful enzymes viz., amylases, proteases, lipases, hydrolases and reductases. Among them amylolytic enzymes have great biotechnological applications and economic exploitations. The production of $\alpha$-amylases by fermentation had been thoroughly investigated and shown to be affected by a variety of physicochemical factors, such as the composition of the growth medium, the type of strain, cell growth, methods of cultivation, inoculum concentration, time of incubation, pH, temperature, salinity, carbon, nitrogen and mineral sources. The present study was carried out to optimize the $\alpha$-amylase production of Brevibacillus borstelensis R1 using ten different media viz., Nutrient broth, Luria Bertain broth, Clarks \& Lub medium, Pikovskaya's medium, Tendler's non-synthetic medium, Amylase production medium, Soluble starch beef extract medium, Soybean casein digest medium, Yeast extract peptone dextrose glucose medium and Tryptone glucose beef extract medium. Among these ten media, Pikovskaya's (PK) medium proved to be optimal for $\alpha$-amylase production $(1861 \pm 17 U / m l)$. The optimized $\alpha$-amylase production in PK medium by submerged fermentation $(S m F)$ was subjected to varying physical parameters such as $24 h r s$ incubation time, $2 \%$ inoculum size, $37^{\circ} \mathrm{C}, \mathrm{pH} 7.0$ and $1 \% \mathrm{NaCl}$. Alpha-amylase produced by B.borostelensis R1 have many applications in starch processing, desizing of textiles, paper sizing, detergent additive, bread improvement, ethanol production, sewage treatment, effluent treatment and other fermentation processes.
\end{abstract}

Keywords: Pikovskaya's medium, incubation time, inoculum size, temperature, pH and salinity.

\section{INTRODUCTION}

Screening is the detection and isolation of high-yielding species from the natural material such as soil, air and water containing heterogeneous microbial populations. Screening methods of bacteria include primary screening, secondary screening and strain improvement [1].

\subsection{Primary Screening}

Primary screening consists of basic elementary tests required to detect and to isolate new bacterial species exhibiting the desired property. Marine microorganisms are known to have a diverse range of enzymatic activity. Several reports of $\alpha$ amylase producing bacteria include: Streptomyces spp. [2], Lactobacillus spp. [3], Geobacillus stearothermophilus spp. [4] and Clostridium spp. [5].

\subsection{Measurements of Bacterial Growth}

Growth is defined as an orderly increase of all cellular components, with multiplication as a consequence. Death is the irreversible loss of ability of organism to reproduce itself. The stages of growth curve are lag phase, log phase (exponential phase), stationary phase and death phase (decline phase) [6].

There are four methods of growth measurements:

\subsubsection{Direct Microscopic Count (Direct Cell Count}

\section{Method)}

It helps to count the total number of cells include both living and dead directly by direct microscopic counts using Petroffhauser chamber (nine squares, each $0.1 \mathrm{~mm}$ deep, volume of liquid over one square $\mathrm{mm}$ is 0.1 cubic $\mathrm{mm}$ ).

\subsubsection{Viable Cell Count Method}

It is based on the principle that when material containing bacteria are cultured, every viable bacterium develops into a visible colony on a nutrient agar medium.

\subsubsection{Turbidity Method}

It helps to study the cloudiness of the suspension. Turbidity is directly proportional to the number of cells. It is quantified 
with the spectrophotometer, which measures the amount of light transmitted directly through a sample. The cells suspended in the culture interrupt the passage of light. The amount of light absorbed through the suspension is measured as optical density.

\subsubsection{Dry Weight Method}

It helps to estimate the bacterial growth at regular time intervals during the incubation period. The growth of the bacteria is directly proportional to the dry weight harvested.

\subsection{Physical Parameters}

The physical parameters include $\mathrm{pH}$, temperature and salinity which influence the production of amylase.

\subsection{1 $\mathbf{P}^{\mathrm{H}}$}

Sudden variations in cytoplasmic $\mathrm{pH}$ can harm bacteria by disrupting the plasma membrane, inhibiting the activity of enzymes and membrane transport proteins. $\mathrm{pH}$ is known to affect the synthesis, secretion and stability of $\alpha$-amylase [7]. Selection of a suitable fermentation medium and initial $\mathrm{pH}$ is very important for the enhanced alpha-amylase production [8].

\subsubsection{Temperature}

High temperatures damage bacteria by denaturing enzymes, transport carriers, and other proteins. Thermostability is a desired characteristic of most of the industrial enzymes. Thermostable $\alpha$-amylases were produced by mesophilic species of Bacillus [9]. Therefore, a high value is placed on extreme thermostability and thermoactivity of the enzymes.

\subsubsection{Salinity}

Bacteria in marine habitat have modified the structure of enzymes, ribosomes, and transport proteins which require high levels of potassium for stability and activity. Halophilic bacteria are classified according to their salt requirement and growth pattern. Slight halophiles show optimum growth at 2$5 \% \mathrm{NaCl}$, moderate halophiles at 5-20\% $\mathrm{NaCl}$ and extreme halophiles at $20-30 \% \mathrm{NaCl}[10]$.

\section{MATERIALS AND METHODS}

\subsection{Collection of the Marine Water Samples}

Marine water samples were collected from Rushikonda coastal area of Visakhapatnam, Andhra Pradesh, India. The water samples were collected in sterile BOD bottles (Borosil) and brought to the lab, stored in the refrigerator until it was used.

\subsection{Primary Screening of $\alpha$-Amylase Producing}

\section{Bacteria}

The collected marine water samples were diluted by serial dilution technique. The diluted samples of $10^{-4}$ to $10^{-6}(0.1 \mathrm{ml})$ were spreaded with L-shaped glass rod by spread plate technique on the starch agar plates. After incubation at $37^{\circ} \mathrm{C}$ for 24 hours, the plates were flooded with Lugol solution (1\% iodine in $2 \%$ potassium iodide $\mathrm{w} / \mathrm{v}$ ) [11]. The average $\mathrm{cfu} / \mathrm{ml}$, number of colonies forming clear halo zone of hydrolysis and zone of starch hydrolysis measured in $\mathrm{mm}$.

\subsection{Estimation of Amylase by DNS Method}

Maltose produced by the hydrolytic activity of $\alpha$-amylase on $\alpha-1,4$ linkages present in polysaccharides, reduce 3,5 dinitro salicylate to an orange red colored 5-nitro 3-amino salicylate which can be measured at $520 \mathrm{~nm}$. The starch substrate $[0.5 \mathrm{ml}$ of $0.5 \%$ in $0.1 \mathrm{M}$ phosphate buffer ( $\mathrm{pH} 6.8$ )] was mixed with $1 \%(0.2 \mathrm{ml}) \mathrm{NaCl}$ in a test tube and pre incubated at $37^{\circ} \mathrm{C}$ for 10 minutes. The supernatant collected from the centrifugation of the production media was used as enzyme source, $0.5 \mathrm{ml}$ of this was added to the reaction mixture. The reaction was terminated by the addition of $1.0 \mathrm{ml}$ of 3,5-dinitrosalicylic acid reagent [1.0 gm DNS in $0.8 \% \mathrm{NaOH}, 60 \% \mathrm{Na} \mathrm{K}$ tartrate] after incubation at $37^{\circ} \mathrm{C}$ for 15 minutes. The contents were mixed well and kept in boiling water bath for 10 minutes. Then they were cooled and diluted with $10 \mathrm{ml}$ of distilled $\mathrm{H}_{2} \mathrm{O}$. The color developed was read at 520nm. One unit of enzyme activity was defined as the amount of enzyme that release $1.0 \mathrm{mmol}$ of reducing sugar (maltose) per minute under the assay conditions [12].

\subsection{Fermentation Media}

Optimization of $\alpha$-amylase production by $B$. borostelensis R 1 was carried out by using ten submerged fermentation media; Nutrient Broth (NB), Luria Bertain Broth (LB), Clarks and Lub Medium (CL), Pikovskaya's Medium (PK), Tendler's Non-synthetic (TNS) Medium, Amylase Production Media (APM), Soluble Starch Beef Extract Medium (SB), Soybean Casein Digest Medium (SCD), Yeast Extract Peptone Dextrose Glucose Medium (YPDG) and Tryptone Glucose Beef Extract Medium (TGB) procured from Himedia, India.

The ingredients of ten fermentation media used for the optimization of $\alpha$-amylase production were in $(\mathrm{g} / \mathrm{l}) \mathbf{N B}(\mathrm{NaCl}$ 5.0, Beef extract 3.0 and Peptic digest of animal tissue 5.0), LB (Tryptone 10.0, Yeast extract 5.0 and $\mathrm{NaCl} 10.0$ ), CL (Glucose 5.0, Peptone 5.0 and $\mathrm{K}_{2} \mathrm{HPO}_{4} 5.0$ ), PK (Glucose 10.00, $\mathrm{Ca}_{3}\left(\mathrm{PO}_{4}\right)_{2}$ 5.0, $\left(\mathrm{NH}_{4}\right)_{2} \mathrm{SO}_{4} 0.50, \mathrm{MgSO}_{4} .7 \mathrm{H}_{2} \mathrm{O} \quad 0.10$, $\mathrm{MnSO}_{4} .7 \mathrm{H}_{2} \mathrm{O} 0.01, \mathrm{FeSO}_{4} 0.01, \mathrm{KCl} 0.20$ and Yeast extract 0.50), TNS (Tryptone 10.0, Yeast extract 4.0, Sodium citrate 0.5 , Ammonium nitrate 1.0, $\mathrm{K}_{2} \mathrm{HPO}_{4} 0.3, \mathrm{MgSO}_{4} 0.5$ and Starch 2.0), APM (Starch 2.0, $\mathrm{Na}_{2} \mathrm{HPO}_{4} 3.0, \mathrm{KH}_{2} \mathrm{PO}_{4} 6.0$, $\mathrm{NH}_{4} \mathrm{Cl} 1.0, \mathrm{CaCl}_{2} 0.15, \mathrm{MgSO}_{4} .7 \mathrm{H}_{2} \mathrm{O} 0.25$, Casein hydrolyte 
0.20 and Yeast Extract 0.10), SB (Soluble Starch 2\%, Beef Extract $1 \%$, Yeast Extract $0.2 \%, \mathrm{CaCl}_{2} \quad 0.02 \%$ and $\mathrm{MgSO}_{4} .7 \mathrm{H}_{2} \mathrm{O} 0.01 \%$ ), SCD (Pancreatic digest of casein 17.00, Soybean meal 3.00, $\mathrm{NaCl} 5.00, \mathrm{KH}_{2} \mathrm{PO}_{4} 2.50$ and Dextrose 2.50), YPDG (Yeast extract 10.00, Peptone 20.00, Glycerol $30.0 \mathrm{ml}$ and Dextrose 1.00), TGB (Tryptone 5.00, Glucose 3.00 and Beef extract 1.00). The final $\mathrm{pH}$ was adjusted to 7.0 with $0.1 \mathrm{~N} \mathrm{HCl}$ and $0.1 \mathrm{~N} \mathrm{NaOH}$ before autoclaving.

\subsection{Incubation Period}

The growth curve of Brevibacillus borstelensis R1was constructed by using direct microscopic count method, viable cell count method, turbidity method and dry weight method in Pikovskaya's Medium. The $\alpha$-amylase production during growth phase (0-30hours) with an interval of $2 \mathrm{hrs}$ of $\mathrm{B}$. borstelensis R1 was assayed by DNS method. The incubation period with maximum amylase production was determined during growth cycle.

\subsection{Inoculum Size}

Two loopful of culture was aseptically inoculated in Pikovskaya's Medium. The flask was incubated $\left(37^{\circ} \mathrm{C}\right)$ in rotary shaking incubator at $120 \mathrm{rpm}$, for $24 \mathrm{hrs}$. After incubation the inoculum optical density was adjusted to 0.9 with sterile distilled water at $600 \mathrm{~nm}$ in colorimeter. Each $\mathrm{ml}$ contains $10^{12}$ cells which were in stationary phase ( $\alpha$-amylase production phase) as calibrated by growth curve measurement methods.

The effect of different sizes ( $1 \%$ to $5 \%$ ) of inoculum on the $\alpha$ amylase production of Brevibacillus borstelensis R1 in Submerged fermentation $(\mathrm{SmF})$ was investigated. The Erlenmeyer flask was incubated $\left(37^{0} \mathrm{C}\right)$ in rotary shaking incubator at $120 \mathrm{rpm}$, for $24 \mathrm{hrs}$.

\subsection{Temperature}

Hundred $\mathrm{ml}$ of the Pikovskaya's Medium was taken in sterile erlenmeyer flasks. Inoculum size $(2 \%)$ of pure culture from pre-incubated pure strain was inoculated to each of flasks. Medium was incubated in orbital shaking incubator (120rpm) at different $\left(4^{0} \mathrm{C}, 25^{\circ} \mathrm{C}, 37^{\circ} \mathrm{C}, 50^{\circ} \mathrm{C}\right.$ and $\left.60^{\circ} \mathrm{C}\right)$ temperatures for 24hrs.

\section{$2.8 \mathrm{pH}$}

Fermentation medium (Pikovskaya's Medium) was prepared at different $\mathrm{pH}(2.0,5.0,7.0,9.0$ and 11.0) by adjusting the $\mathrm{pH}$ with $0.1 \mathrm{~N} \mathrm{HCl}$ and $0.1 \mathrm{~N} \mathrm{NaOH}$. Hundred $\mathrm{ml}$ of different $\mathrm{pH}$ medium were taken in sterile erlenmeyer flasks. Inoculum size (2\%) from preincubated pure strain was inoculated to each of Erlenmeyer flask. The flasks were incubated in orbital shaking incubator $(120 \mathrm{rpm})$ at $37^{\circ} \mathrm{C}$ for $24 \mathrm{hrs}$.

\subsection{Salinity}

Hundred $\mathrm{ml}$ of the Pikovskaya's Medium was taken in different erlenmeyer flasks. Inoculum size (2\%) of pure culture from preincubated pure strain was inoculated to each Erlenmeyer flask. Each flask with different concentrations of $\mathrm{NaCl}(0.5,1.0,1.5,2.0$, and $2.5 \% \mathrm{w} / \mathrm{v})$ was incubated in orbital shaking incubator (120rpm) at $37^{\circ} \mathrm{C}$ for $24 \mathrm{hrs}$.

After incubation, the samples were subjected to centrifugation at 5,000 rpm for 15 minutes at $25^{\circ} \mathrm{C}$. The supernatant was collected in sterile test tubes and the pellet was discarded. Supernatant $(0.5 \mathrm{ml})$ was used for the amylase assay by DNS method.

\section{RESULTS}

\subsection{Optimization of the Media}

The optimization of media for $\alpha$-amylase production was carried out by inoculating B. borostelensis R1 for $24 \mathrm{hrs}$ in ten different submerged fermentation media- Nutrient Broth (NB), Luria Bertain Broth (LB), Clarks and Lub Medium (CL), Pikovskaya's (PK) Medium, Tendler's Non-synthetic Medium (TNS), Amylase Production Medium (APM), Soluble Starch Beef Extract Medium (SB), Soybean Casein Digest Medium (SCD), Yeast Extract peptone Dextrose Glucose Medium (YPDG) and Tryptone Glucose Beef Extract (TGB) Medium. The highest production of $\alpha$-amylase in all media is shown in Chart -1 . The optimal production of amylase $(1861 \pm 17 \mathrm{U} / \mathrm{ml})$ was observed when R1 strain was subjected to $\mathrm{SmF}$ in Pikovskaya's (PK) production media.

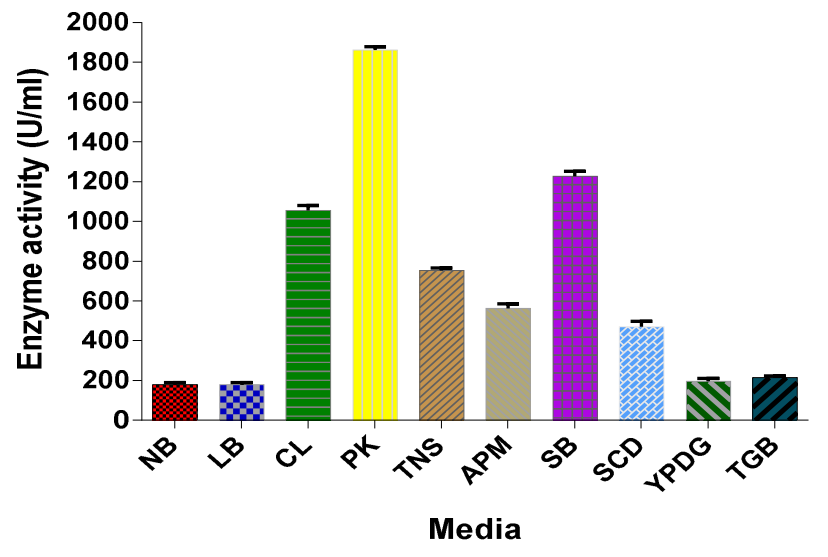

Chart -1: The $\alpha$-amylase production $(\mathrm{U} / \mathrm{ml})$ in various submerged fermentation (SmF) media; Nutrient broth (NB),

Luria bertain broth (LB), Clarks and lub medium (CL), Pikovskaya's medium (PK), Tendler's non-synthetic medium (TNS), Amylase production medium (APM), Soluble starch beef extract medium (SB), Soybean casein digest medium (SCD), Yeast extract peptone glycerol glucose medium (YPDG) and Tryptone glucose beef extract medium (TGB). 
$\mathrm{Y}$ bars indicate the standard deviation of mean value.

$* * * * \mathrm{P}<0.0001$ Values differ significantly at $\mathrm{p}<0.05$

The optimum $(1861 \pm 17 \mathrm{U} / \mathrm{ml}) \alpha$-amylase production was observed with Pikovskaya's Medium (PK) and the lowest production was observed $(180 \pm 1 \mathrm{U} / \mathrm{ml})$ with two mediaNutrient broth and Luria bertain broth (Chart -1).

\subsection{Incubation Period}

Measurements of growth curve of B. borstelensis R1 to determine incubation period: The growth curve of $B$. borstelensis R1 at stationary phase was constant from 18- 24hours. It was measured by adopting direct microscopic count by using Neubauer chamber, $12 \log \mathrm{cfu} / \mathrm{ml}$ (Chart -2a), viable cell count method, $12 \mathrm{cfu} / \mathrm{ml}$ (Chart $-2 \mathrm{~b}$ ), turbidity method, $0.923 \pm 0.012$ O.D at $600 \mathrm{~nm}$ (Chart $-2 \mathrm{c}$ ) and dry weight method, $1.526667 \pm 0.003 \mathrm{gm} / 10 \mathrm{ml}$ (Chart $-2 \mathrm{~d}$ ). Distinct phases of the growth curve were observed in each method.

The Rate of Growth (R) measured by direct microscopic count, viable standard plate count method and turbidity method was 1.63 . The specific growth rate $(\mu)$ was 1.65 and the generation time $(\mathrm{G})$ was $0.61 \mathrm{hrs}$ or 36.60 minutes.

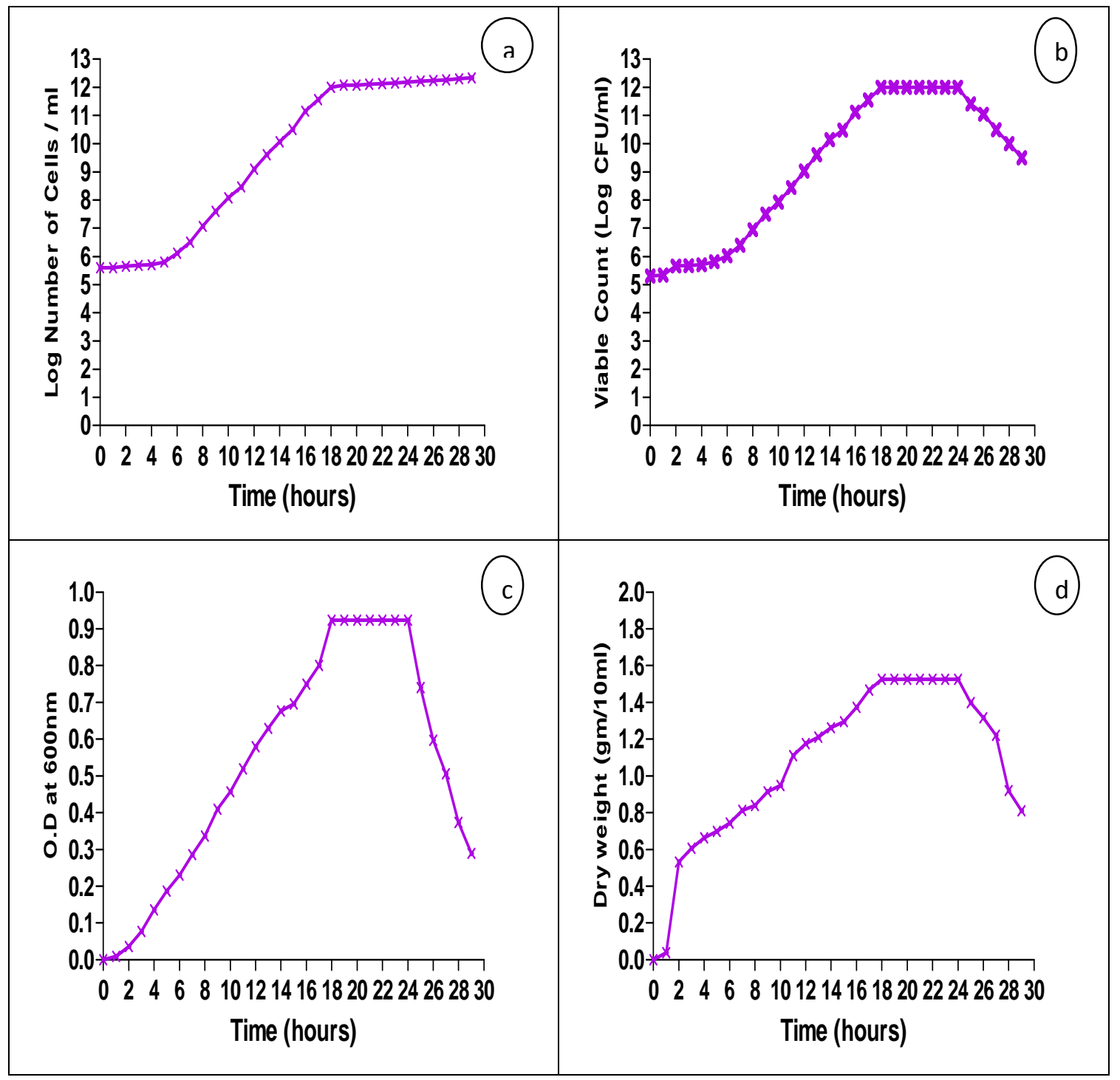

Chart -2: Growth curve of Brevibacillus borstelensis R1: a, Direct microscopic count method; b, Viable cell count method; c, Turbidity method and d, Dry weight method. 
$\mathrm{Y}$ bars indicate the standard deviation of mean value.

**** $\mathrm{P}<0.0001$ Values differ significantly at $\mathrm{p}<0.05$ with moderate degree of positive correlation.

The Pikovskaya's (PK) Medium was found to be the best among ten fermentation media used. The lag phase $(0-2 \mathrm{hrs})$, log phase (2-18hrs), stationary phase (18-24hrs) and decline phase followed. The highest $\alpha$-amylase production $(1,800 \mathrm{U} / \mathrm{ml})$ was found during the stationary phase $(18-24 \mathrm{hrs})$ (Chart -3). Amylase production at 24hours was taken as standard time in all the following experiments.

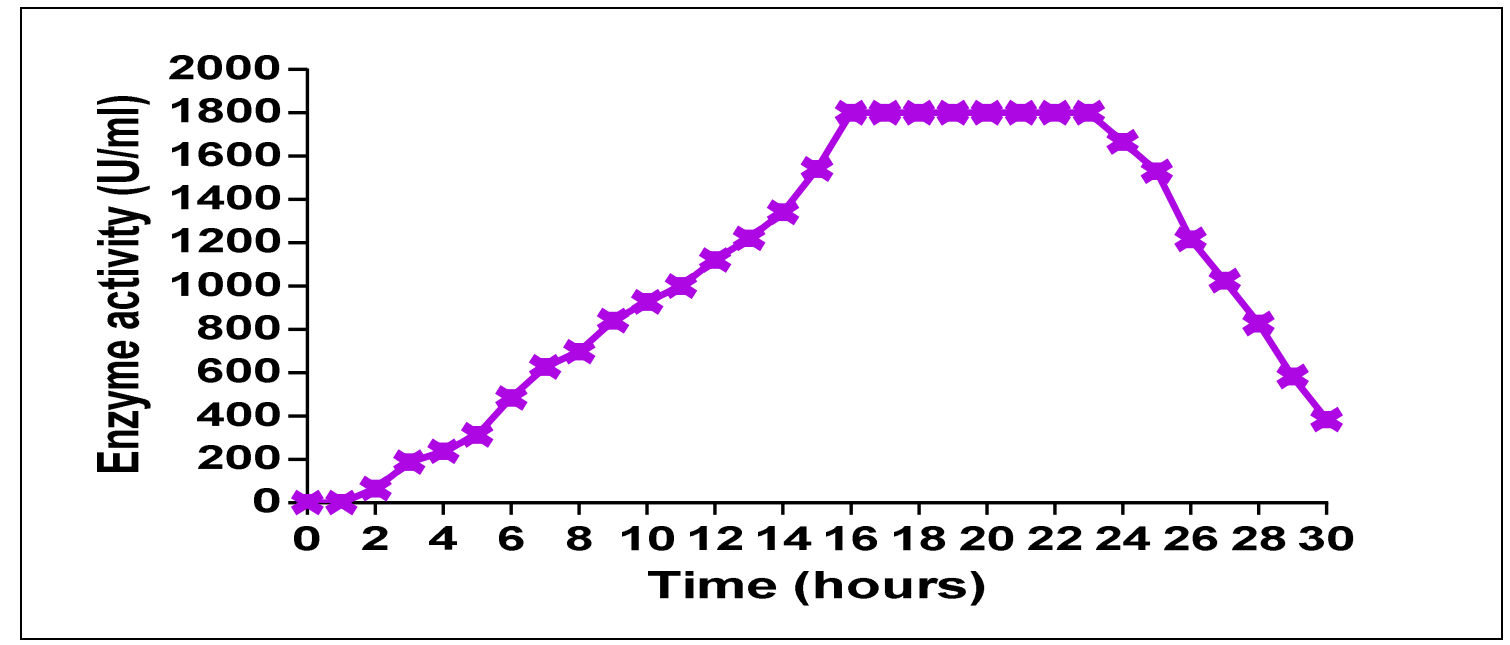

Chart -3: Effect of incubation period on $\alpha$-amylase production of Brevibacillus borstelensis R1

$\mathrm{Y}$ bars indicate the standard deviation of mean value.

$* * * * \mathrm{P}<0.0001$ Values differ significantly at $\mathrm{p}<0.05$ with moderate degree of positive correlation.

\subsection{Inoculum size}

The Pikovskaya's (PK) Medium and incubation period (24hrs) were optimized. The optimum inoculum size was optimized in PK medium. The effect of different sizes (1\% to $5 \%)$ of inoculum on the production of $\alpha$-amylase by Brevibacillus borstelensis R1 using submerged fermentation (SmF) was investigated. The production of amylase was increased with the increase in the level of inoculum upto $2 \%(1813 \pm 23 \mathrm{U} / \mathrm{ml})$. As the level of inoculum was further increased, the productivity of amylase was decreased (Chart -4$)$. Thus, the inoculum level of $2 \% \mathrm{v} / \mathrm{w}$ was found to be optimum for $\alpha$ amylase synthesis.

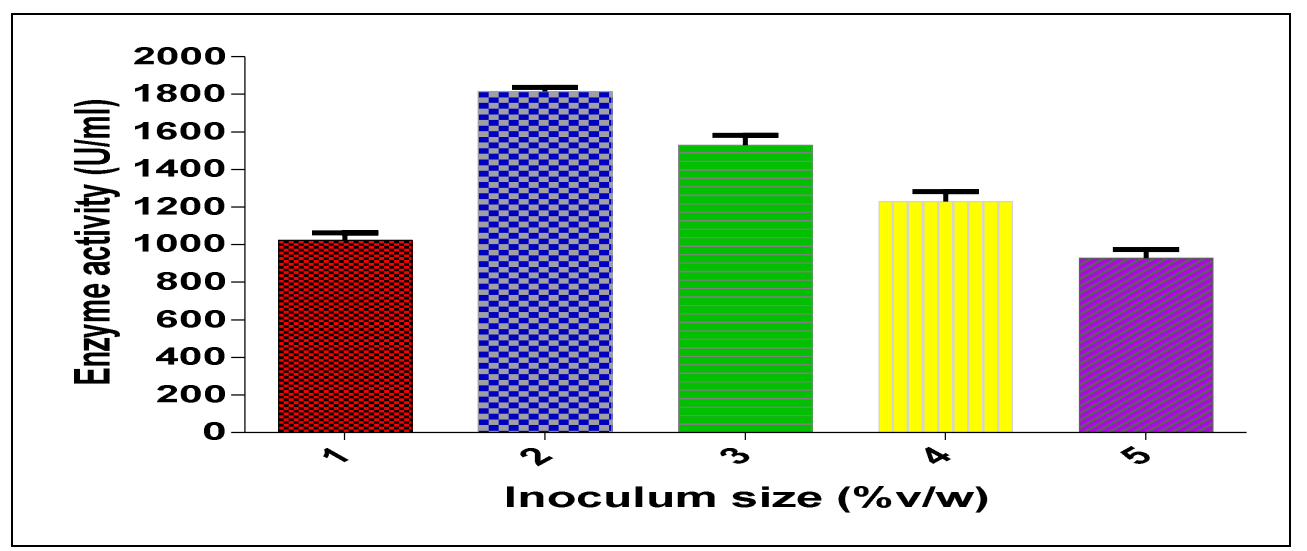

Chart -4: Effect of inoculum size on $\alpha$-amylase production of Brevibacillus borstelensis R1 
$\mathrm{Y}$ bars indicate the standard deviation of mean value.

$* * * * \mathrm{P}<0.0001$ Values differ significantly at $\mathrm{p}<0.05$

\subsection{Temperature}

The Pikovskaya's (PK) Medium, incubation period (24hrs) and $2 \%$ inoculum size were optimized. The optimization of temperature was carried at different temperatures $\left(4^{0} \mathrm{C}, 25^{\circ} \mathrm{C}\right.$, $\left.37^{\circ} \mathrm{C}, 50^{\circ} \mathrm{C} \& 60^{\circ} \mathrm{C}\right)$. The highest amylase activity was recorded at $37^{\circ} \mathrm{C}(2086 \pm 71 \mathrm{U} / \mathrm{ml})$ and the lowest at $4^{0} \mathrm{C}$ $(1131 \pm 57 \mathrm{U} / \mathrm{ml})($ Chart -5$)$.

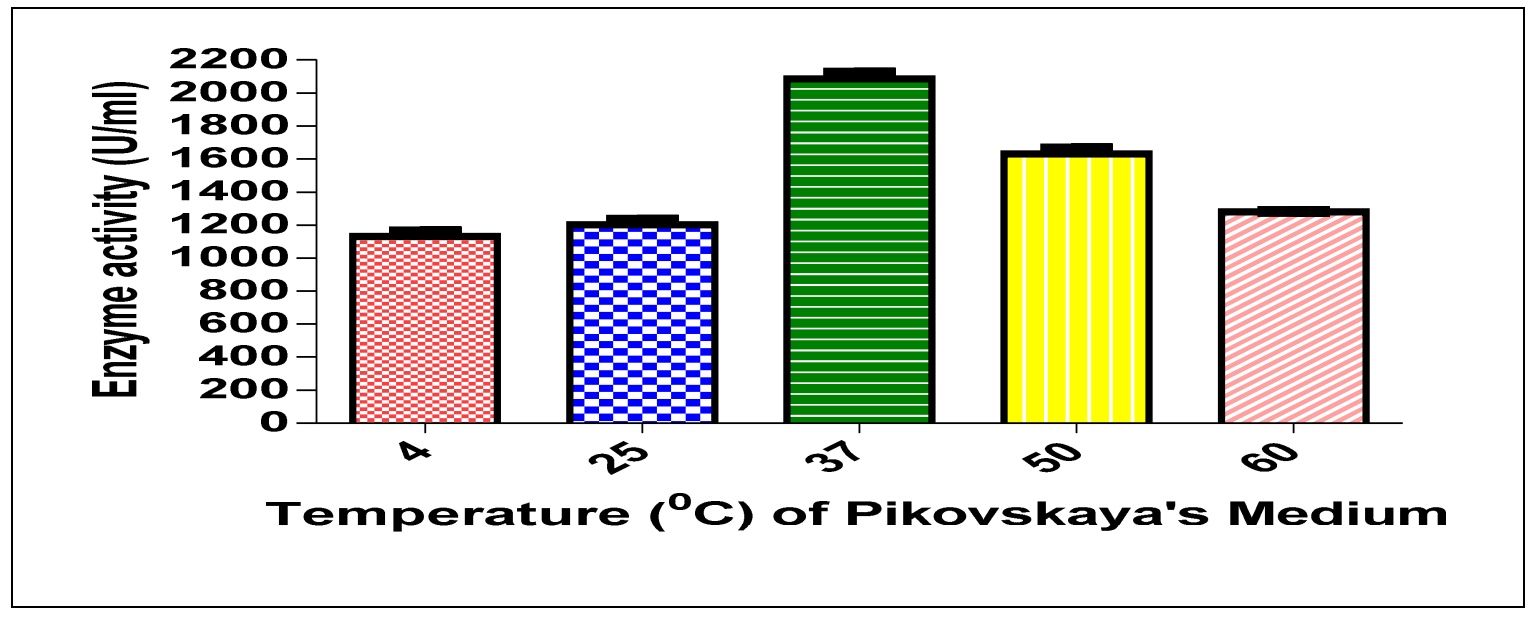

Chart -5: Effect of Temperature on $\alpha$-amylase production of Brevibacillus borstelensis R1

Y bars indicate the standard deviation of mean value.

$* * * * \mathrm{P}<0.0001$ Values differ significantly at $\mathrm{p}<0.05$

\section{$3.5 \mathrm{pH}$}

The Pikovskaya's (PK) Medium, incubation period (24hrs), $2 \%$ inoculum size and temperature $\left(37^{\circ} \mathrm{C}\right)$ were optimized.
The optimization of $\mathrm{pH}$ was carried with different $\mathrm{pH}(2,5,7$, $9 \& 11)$. The $\mathrm{pH}$ was adjusted by using $0.1 \mathrm{~N} \mathrm{HCl}$ and $0.1 \mathrm{~N}$ $\mathrm{NaOH}$. The highest amylase activity was recorded at $\mathrm{pH} 7.0$ $(2083 \pm 56 \mathrm{U} / \mathrm{ml})$ and the lowest at $\mathrm{pH} 11.0(565 \pm 77 \mathrm{U} / \mathrm{ml})$ (Chart -6).

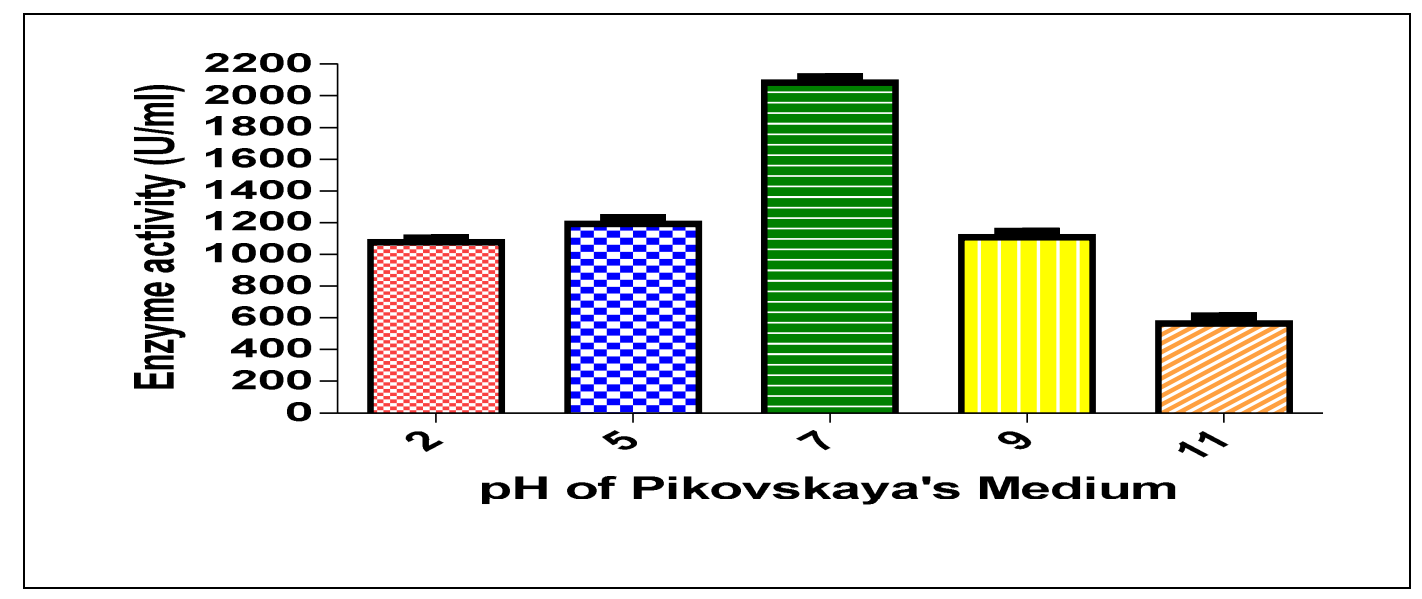

Chart -6: Effect of $\mathrm{pH}$ on $\alpha$-amylase production of Brevibacillus borstelensis $\mathrm{R} 1$ 
$\mathrm{Y}$ bars indicate the standard deviation of mean value.

$* * * * \mathrm{P}<0.0001$ Values differ significantly at $\mathrm{p}<0.05$

\subsection{Salinity}

The Pikovskaya's (PK) Medium, incubation period (24hrs), $2 \%$ inoculum size, temperature $\left(37^{\circ} \mathrm{C}\right)$ and $\mathrm{pH}(7.0)$ were optimized. The optimization of salinity at different concentrations $(0.5 \%, 1.0 \%, 1.5 \%, 2.0 \% \& 2.5 \%)$ is depicted in Chart -7. The highest amylase activity was recorded at salinity of $1.0 \%(2082 \pm 58 \mathrm{U} / \mathrm{ml})$ and the lowest at $2.0 \%$ (1121 $\pm 59 \mathrm{U} / \mathrm{ml})$.

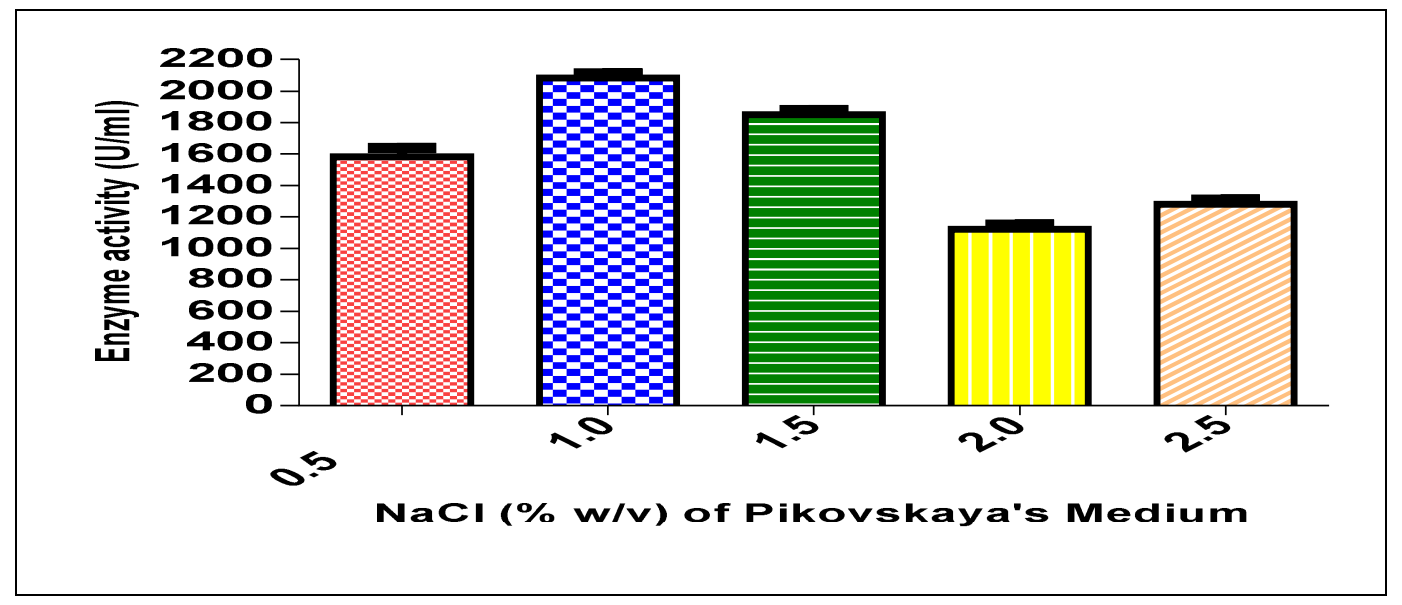

Chart -7: Effect of salinity on $\alpha$-amylase production of Brevibacillus borstelensis R1

$\mathrm{Y}$ bars indicate the standard deviation of mean value.

$* * * * \mathrm{P}<0.0001$ Values differ significantly at $\mathrm{p}<0.05$

\section{DISCUSSION}

The present work was carried out in one medium selected from ten media to optimize the physical and chemical parameters. The highest $\alpha$-amylase production was found in Pikovskaya's Medium (PK) and the lowest in Nutrient broth and Luria bertain broth. The highest $\alpha$-amylase production $(1,800 \mathrm{U} / \mathrm{ml})$ was found during the stationary phase $(18-24 \mathrm{hrs})$. The production of amylase was increased with the increase in the level of inoculum at $2 \%(1813 \pm 23 \mathrm{U} / \mathrm{ml})$. The highest amylase activity was recorded at $37^{\circ} \mathrm{C}(2086 \pm 71 \mathrm{U} / \mathrm{ml}), \mathrm{pH} 7.0$ $(2083 \pm 56 \mathrm{U} / \mathrm{ml})$ and at salinity $1.0 \%(2082 \pm 58 \mathrm{U} / \mathrm{ml})$ and the lowest at $4^{\circ} \mathrm{C}, \mathrm{pH} 11.0$ and at salinity $2.0 \%$.

The amylase production after 72hours of growth (Bacillus subtilis) was maximum (370U/mg). The effects of incubation period, $\mathrm{pH}$ of the medium and incubation temperature were optimized. The maximum production of enzyme was obtained at $30^{\circ} \mathrm{C}$ and $\mathrm{pH} 7.0$ [13]. The production of the enzyme by Bacillus $s p$. was maximum at $10 \mathrm{hrs}$ after inoculation [14]. The enzyme production largely dependent on the type of strain, composition of medium, cell growth, initial $\mathrm{pH}$ and thermo stability $[15,16]$.Increased incubation period decreased the $\alpha$ amylase production. It might be due the depletion of nutrients, accumulation of toxic byproducts in the medium, proteolysis of $\alpha$-amylase and microorganisms [17]. To obtain maximum enzyme yield, development of a suitable medium and culture conditions were obligatory [18].

Raj Devi \& Yogeesvaran [19] reported that the maximum enzyme production obtained after $24 \mathrm{hrs}$ of incubation in case of Bacillus amyloliquefaciens and 48hrs of incubation with Micrococcus halobius. The production of the enzyme was maximum at $10 \mathrm{hrs}$ after inoculation with Bacillus sp. [20]. Maximum growth was shown at $48 \mathrm{hrs}$ and amylase activity at 24hrs [21].

In the literature survey the optimum amylase production was delineated by several authors in different media. In acidic conditions ( $\mathrm{pH} 4.0$ - 6.5) the amylase production was reported in Bacillus spp. [22].In neutral conditions ( $\mathrm{pH} 6.5$ - 7.5) the amylase production was reported in Bacillus spp. [23]. In alkaline conditions ( $\mathrm{pH} 7.5$ - 11) the $\alpha$-amylase production was reported in Bacillus spp. [24].

The production was highest in Pikovskaya's Medium at $37^{\circ} \mathrm{C}$. The amylase production in different media was reported in psychrophilic conditions (Temp. $4^{0} \mathrm{C}$ ) in Nocardiopsis sp. 7326 [25] and Arthrobacter psychrolactophilus [26].The zenith amylase production of mesophilic Bacillus spp. (Temperature $30^{0}-45^{\circ} \mathrm{C}$ ) was communicated by Nagarajan et al. [27].. 
The amylase production of Brevibacillus borostelensis R1 was most favorable in Pikovskaya's medium with augment of $1 \%$ $\mathrm{NaCl}$. The $\mathrm{NaCl} \%$ source of metal ion was reported to have a stirring effect on the production of amylase was disclosed in Bacillus spp. by Ashabil Aygan [28]. Parallel work with different $\mathrm{NaCl}$ concentrations $(0.5-1.5 \%)$ was carried out in Bacillus spp. [29]. But subduced effect was reported in Bacillus sp. [30].

\section{CONCLUSIONS}

The present study was carried out to optimize the $\alpha$-amylase production of Brevibacillus borstelensis R1 using ten different media. Among these ten media, Pikovskaya's (PK) medium proved to be optimal for $\alpha$-amylase production $(1861 \pm 17 \mathrm{U} / \mathrm{ml})$.

The optimized $\alpha$-amylase production in PK medium by submerged fermentation ( $\mathrm{SmF}$ ) was subjected to varying physical parameters such as $24 \mathrm{hrs}$ incubation time, $2 \%$ inoculum size, $37^{\circ} \mathrm{C}, \mathrm{pH} 7.0$ and $1 \% \mathrm{NaCl}$ ).

\section{ACKNOWLEDGEMENTS}

We thank Management of Dr.Lankapalli Bullayya College, Visakhapatnam for the financial support and facilities provided to make this work possible.

\section{REFERENCES}

[1]. Patel AH (2003) Industrial Microbiology, Pub. by Rajiv Beri for Macmillan India Ltd., pp 15-35.

[2]. Kar S and Ray RC (2008) Statistical optimization of alphaamylase production by Streptomyces erumpens MTCC 7317 cells in calcium alginate beads using response surface methodology Pol. J. Microbiol. 57: 49-57.

[3]. Smita HP, Mnas RS, Shaktimay K, Ramesh CR and Dider M (2008) Statistical optimization of $\alpha$-amylase production from probiotic Lactobacillus plantarum MTCC1407 in submerged fermentation. Polish J. Microbiol. 57: 149-155.

[4]. Zareian S, Khajeh K, Ranjbar B, Dabirmanesh B, Ghollasi M and Mollania N (2010) Purification and characterization of a novel amylopullulanase that converts pullulan to glucose, maltose, and maltotriose and starch to glucose and maltose. Enzyme and Microbial Technology 46: 57-63.

[5]. Mrudula S (2010) Optimization of thermostable amylopullulanase production in solid state fermentation by Clostridium thermosulfurogenes SVM17 through PlackettBurman and response surface methodological approaches. Malaysian J. of Microbio. 6: 181-195.

[6]. Wulf Crueger and Anneliese Crueer (2004) A textbook of Industrial Microbiology, Second edition. Panima Publishing Corporation, pp.1-121.

[7]. Fogarty MW (1983) Microbial Amylases. In; Microbial Enzymes and Biotechnology, W.M. Fogarty (9 Ed.), Applied Science Publishers Ltd., London, UK, 1-92.
[8]. Hughes MN and Poole R K (1991) Metal specification and microbial growth-the hard (and soft) facts. J. Gen. Microbiol. 137:725-734.

[9]. Burhan A, Nisa U, Gökhan C, Ömer C, Ashabil A and Osman G (2003) Enzymatic properties of a novel thermostable, thermophilic, alkaline and chelator resistant amylase from an alkaliphilic Bacillus sp. Isolate ANT-6. Proc. Biochem. 38: 1397-1403.

[10]. Mohammed Kuddus and Roohi (2010) Microbial coldactive $\alpha$-amylases: From fundamentals to recent Developments, Cur. Rese. Techno. and Edu. Topics in Appl. Microbio. and Microb. Biotechn. A.Mendez-vilas (Ed.)

[11]. Amoozegar MA, Malekzadeh F and Malik KA (2003) Production of amylase by newly isolated moderate halophile, Halobacillus sp. Strain MA-2. J. Microbio. Meth. 52: 353-359. [12]. Miller GL (1959) Use of Dinitro salicylic acid reagent for determination of reducing sugar. Analy. Chem. 31: 426 429.

[13]. Harikrishna Yadav, Nanganurum, Narasimhulu, Korrapatim Satish and Mutyala (2012) Studies of the production of $\alpha$-amylase by Bacillus subtilis IOSR J. of Eng. 2(5): 1053-1055.

[14]. Pushpendra Singh, Paras Gupta, Ravindra Singh and Rajesh Sharma (2012) Factors affecting $\alpha$ - Amylase Production on Submerged Fermentation by Bacillus sp. Int. J. of Pharm. \& Life Sci. (IJPLS), 3(12): 2243-2246.

[15]. Haq I, Ashraf H, Rani S and Qadeer M A (2002) Biosynthesis of alpha amylase by chemically treated mutant of Bacillus subtilis GCBU-20, Pak. J. Biol. Sci. 2: 73-75.

[16]. Haq I, Shamim N, Ashraf H, Ali S and Qadeer MA(2005) Effect of surfactants on the biosynthesis of alphaamylase by Bacillus subtilis GCBM-25. Pak. J. Bot. 37: 373379.

[17]. Yang C and Liu W (2004) Purification and properties of a maltotriose-producing $\alpha$-amylase from Thermobifida fusca. Enz. Microbial. Technol. 35: 254-260.

[18]. Ray RC, Kar S and Nayak S (2008) Extracellular $\alpha$ amylase production by Bacillus brevis MTCC 7521. Food Biotechnol. 22: 234-246.

[19]. Raj Devi PK and Yogeesvaran G (1999) Co-expression of saccharifying alkaline amylase and pullulanase in Micrococcus halobius OR-1 isolated from tapioca cultivar soil, Wo. J.Microbiol. Biotechnol. 15: 223-229.

[20]. Pushpendra Singh, Paras Gupta, Ravindra Singh and Rajesh Sharma (2012) Factors affecting $\alpha$ - Amylase Production on Submerged Fermentation by Bacillus sp. Int. J. of Pharm. \& Life Sci. (IJPLS), 3(12): 2243-2246.

[21]. Srividya Shivakumar (2012) Co-production of alkaline protease and amylase of Bacillus sp. $\mathrm{Y}$ in solid state cultivations. Res. J. Biotech. 7 (2): 32-38.

[22]. Asoodeh A, Chamani J and Lagzian M (2010) A novel thermostable, acidophilic alpha-amylase from a new thermophilic Bacillus sp. Ferdowsicous isolated from Ferdows hot mineral spring in Iran: Purification and biochemical characterization. Int. J. Biol. Macromol. 46: 289-297. 
[23]. Asgher M, Javaid Asad M, Rahman SU and Legge RL (2007) A thermostable $\alpha$-amylase from a moderately thermophilic Bacillus subtilis strain for starch processing. J. Food Eng. 79: 950-955.

[24]. Saxena L, lyer BK and Ananthanarayan L (2007) Three phase-partitioning as a novel method for purification of ragi (Eleusine coracana) bifunctional amylase /protease inhibitor. Process Biochem . 42:491-595.

[25]. Siddiqui ZS, Shaukat SS and Zaman AU (2006) Alleviation of salinity-induced dormancy by growth regulators in wheat seeds. Turk. J. of Bot. 30: 321-330.

[26]. Michael R, Smith AE and James C Zahnley (2005) Production of amylase by Arthrobacter psychrolactophilus. J. Ind. Microbiol. Biotechnol. 32: 277-283.

[27]. Nagarajan $M$, Deborah Paripuranam $T$ and Umamaheswari S (2010) Efficient production of Alphaamylase from agro residues using Bacillus subtilis. J. Chem. Pharm. Res. 2:442-448.

[28]. Ashabil Aygan, Burhan Arikan, Hatice Korkmaz, Sadik Dinçer and Ömer Çolak (2008) Highly thermostable and alkaline $\alpha$-amylase from a halotolerant alkaliphilic Bacillus sp. Ab68, Braz. J. of microb. 39:547-553.

[29]. Bal S, Mishra RR, Rath B, Sahu HK and Thatoi HN (2009) Characterization and extracellular enzyme activity of predominant marine Bacillus spp. isolated from sea water of Orissa Coast, India. Malaysian J. of Microbio. 5: 87-93.

[30]. Muhammad Hamad Ashraf (2004) Thesis Studies on the Biosynthesis of Alpha Amylase by a mutant strain of Bacillus sp. 398.

\section{BIOGRAPHIES}

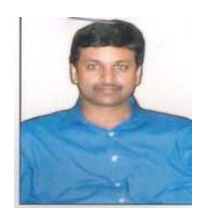

Dr. K.Suribabu, Assistant Professor, PG Department of Microbiology and Research Centre, Dr.Lankapalli Bullayya PG College, Andhra Pradesh, India,Visakhapatnam-530 013,ksuribabu_sda@yahoo.com

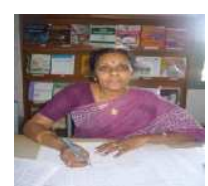

Dr.T.Lalitha Govardhan, Associate Professor, PG Department of Microbiology and Research Centre, Dr.Lankapalli Bullayya Post-graduate College, Andhra Pradesh, India,Visakhapatnam-530 013,

drlalithagovardhan@gmail.com

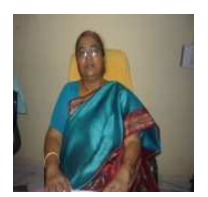

Professor K.P.J Hemalatha, Department Microbiology, Andhra University, Andhra Pradesh, India,kpjhemalatha@gmail.com 